Taubaldiyeva D.S., Iskakova Z.E., Kokeyeva D.M.

India and Kazakstan: Economic relationship

Таубалдиева А.С., Искакова 3.Е., Кокеева А.M.

Үндістан және Қазақстан: экономикамық қатынастар

Таубалдиева А.С., Искакова 3.Е., Кокеева А.M.

Индия и Казахстан: экономические отношения
The article is dedicated to study of development of Kazakhstani-Indian relations in the spheres of economic. The article contains materials that have been found from English sources.

Key words: partnership, economic relations, evolution of relations, bilateral documents.

Мақала экономика саласындағы қазақ-үнді қатынастарының дамуына арналған. Автор ағылшын тілінде табылған мәліметті жариялап отыр.

Түйін сөздер: ынтымақтастық, экономикалық байланыстар, қатынастар дамуы, екі жақты құжаттар.

Статья посвящена изучению развития казахстанско-индийских отношений в области экономики. Автором опубликованы данные, взятые из англоязычных источников.

Кмючевые слова: сотрудничество, экономические связи, эволюция отношений, Авусторонние Аокументы. 


\section{INDIA AND KAZAKSTAN: ECONOMIC RELATIONSHIP}

\section{Introduction}

Central Asia is an interesting region for trade and investment, given its geographical situation (between China, Russia and the Muslim world, as well as the intersection of Asia and Europe) [1], almost total proficiency and rich power resources [2].

India was one of the first to recognize independence of Kazakstan [3]. Many agreements were signed on trade agreements, science and technology etc.

Kazakstan has the second biggest oil resources, and is the second biggest oil maker to Russia among the ex-Soviet republics. Furthermore, the nation has extensive reserves of natural gas. Whenever oil fields are utilized at full capacity, they could make Kazakstan as world's fifth oil maker in the observable future.

Regarding the economic ties between India and Central Asia in the energy sector, Kazakstan will be of incredible significance to India. With evaluated oil reserves of 30 billion barrels [4], proven natural gas assets of 85 trillion cubic feet (Tcf) [5], and other mineral resources, Kazakstan developed its key oil fields: Tengiz, Karachaganak and Kashagan [6].

On this background, Central Asian countries, especially Kazakstan, are growing their energy potential, as more oil, gas and coal are produced. Also, there is presently an effort to develop modern infrastructure and to develop pipeline grids outside the region, and transport services. This course will improve capital investment into Central Asian countries and will bring them on the threshold of great energy prospects.

Deposits of hydrocarbons are immense, particularly, those of gas. There are also reserves of coal and uranium, and hydropower potential.

The main trial Kazakstan faces today is to get over its prevalent dependence on mineral resources through diversifying into such industries as food processing, pharmaceuticals, transport, finance, telecommunications, construction and so on. With the chances to develop a number of key industries and upgrading its services, Kazakstan offers gigantic prospects for investment and trade. Its circumstances are perplexed by the fact that Kazakstan is rich with huge commercial reserves of most minerals on the Mendeleev Table. 
Kazakstan is the second biggest holder of uranium, chromium, lead, and zinc, and among the ten largest sources of coal, manganese, copper, iron, and gold. Additionally, Kazakstan has the 11th largest proven reserves of both oil and natural gas. Mining accounts for 61.6 percent of industrial output. The Kazak Government is trying to utilize accessible strategy instruments to stimulate value-addition, manufacturing, industry, agriculture and services in its GDP synthesis.

Kazakstan is a vital partner for India beyond its abundance of energy resources.

\section{Contemporary Relations}

Commercial and economic relationship between Kazakstan and India is developing and growing.

In oil consumption, India is the fourth [7] after the USA, ROC and Japan. India is also one of the largest importers of liquid hydrocarbons. India's energy consumption is expected to rise at an annual rate of 3.6-4.3\%, and thus would more than double by 2030 . This makes India third largest oil importer by 2025 . Currently, oil imports account for roughly $80 \%$ of the consumed oil. The oil is mostly supplied by the countries of the Persian Gulf [8], namely Iran and Saudi Arabia, also by Nigeria. Any risk of longrun instability in navigation in the Strait of Hormuz may paralyze India's economy. India values Central Asia as an additional source of energy carriers. Central Asia's significance as a treasure house of mineral resources grows up, as raw materials in geographically close regions get exhausted.

Currently, a few private Indian firms have substantial footprints in Kazakstan, for example, Mittal Steel, Punjab National Bank, OVL, KEC International Ltd., Larsen Turbo, Punj Lloyd, etc. They have been dynamic in electric transmission lines, development of oil and gas pipelines, IT etc. Indian organizations are likewise active at tenders for infrastructure and development contracts in Kazakstan, like in telecommunications, power generation, electric energy transmission and distribution, rail and road development, and so on. As indicated by the official information, over 500 joint ventures have been opened in Kazakstan, 190 of which being completely financed by the Indian money. Since recently, Kazak businesses have been setting up their operations in India, too. Among major Kazak firms, represented in India, are KazStroyService (infrastructure), Caspian Shelf (oil exploration), STL (logistics and transportation), and TVL (retail hardware).

During the last quarter of a century, Kazakstan's external policy, generally designed and carried out by President Nazarbayev, has concentrated on expanding and cementing relations with the major partners, developing a safe and sound environment in the region. Availing of the advantages of the location at the very centre of the Eurasian continent, Kazakstan can gain from commerce streams between Asian and European markets, directed both lines, that is, East-West and North-South. The path to taking advantage of Kazakstan's geographical situation lies through strengthening relations between the East and the West, and to promote the wider Central Asia's integration into the world community.

As of now, Kazakstan's share in India's trade with the Central Asian countries is over $50 \%$. Mutual trade between Kazakstan and India grew from nearly 700 million dollars in 2013 to over 1,3 billion dollars in 2014, which confirmed that Kazakstan continued to be the main trade partner of India in Central Asian region in terms of both exports and imports. Data for January-April 2015 are not as promising yet, or the current data is not as accurate, it will be seen later.

A greatest obstacle to developing our mutual trade is the absence of a common border, of a stable direct channel. In this sense, the development of new North-South transport corridors will greatly assist improving trade and economic ties between the two countries. This investment into infrastructure will cut to a half or even less the hauling mileage and lessen shipment costs.

The Kazakstan - Turkmenistan - Iran railway link, as a part of the North-South Transport Corridor, was completed by December 2014, and inaugurated by the three Presidents on 3 December 2014.

This new route will advance resource-rich Central Asia's access to markets South Asian and Middle Eastern markets.

The railway links Zhanaozen in Kazakstan with Bereket-Etrek in Turkmenistan and ends at Gorgan in Golestan province of Iran, where it is connected to the national network that provides access to the Persian Gulf ports and further to South Asian ports.

Indian ONGC Videsh Limited (OVL) has been participating in the Eurasia Project, currently working on the offshore field Satpaev, in the NorthWestern part of the Kazakstan's sector of the Caspian Sea (KSCS).

Satpayev Operating LLP, its operator, has already started applying for the permit to start exploratory drilling, expected to continue till 2016.

The operator's shareholders are KazMunaiGas with $75 \%$, and the Indian company ONGC Videsh Oil with $25 \%$, which is fully financing the project. If the operator discovers commercial reserves of oil, 
the Indian company is authorised to buy more $10 \%$ of the shares.

The Company's forecast shows recoverable reserves of at least quarter a billion tons of oil. If this proves to be the case, the overall capital expenditures on developing the commercial field may be as high as $\$ 9$ billion, including the well and infrastructure construction. The peak extraction level could be 287 thousand $\mathrm{b} / \mathrm{d}$, however unclear how soon this may happen.

ONGC Videsh, as a subsidiary of the stateowned Oil and Natural Gas Corp, eyes to buy oil and gas assets throughout the world to guarantee the smooth energy supply for India.

In 2014, Indians' proposal to set up a joint working group to study the prospects of building a pipeline from Shymkent in the southern Kazakstan to the border of India got a positive response in Kazakstan. However, no noteworthy development has been heard of so far.

Since 2010, Kazakstan's engineering, procurement and construction firm KazStroyService (KSS) has signed Indian infrastructure development contracts worth over $\$ 600$ million.

In November 2014, it was assigned ratings by Moody's Investors Service for the first time ever: a $\mathrm{Ba} 3$ corporate family rating (CFR) and a Ba3-PD probability of default rating (PDR), with the outlook on the ratings being stable.

Azimut Energy Services, another Kazak company, concluded an agreement with Cairn India Ltd. to implement a seismic survey in the Indian state of Rajasthan.

Amid his official visit to India in March 2013, Kazak Foreign Minister Erlan Idrissov asked Indian enterprises to fortify business-to-business relations with Kazakstani companies. A few prominent businesspeople actively responded to the appeal. Mr Rajan Madhu who solved every legal formality for registering the India-Kazakstan Chamber of Commerce and Industry (CCI) in New-Delhi. The Chamber is founded to guard and encourage business prospects in both Indian and Kazak markets, and also to start opening joint ventures in different economic areas. It is hoped that the National Chamber of Entrepreneurs of Kazakstan, established in July 2013, will similarly give distinct importance to founding a twin entity with the IndiaKazakstan CCI.

Eurasian Economic Council's Board Chairman Viktor Khristenko and Indian Industry and Trade Minister Nirmala Sitharaman raised an initiative of concluding a free trade agreement between EEU and its member-states and India. EEC experts, corresponding ministries and departments of EEU member states and India have been studying prospects of creating a free trade zone between EEU and India. Following the results, a special report and recommendations are to be presented to the Supreme Eurasian Economic Council at the level of Heads of State for further steps.

Indians are also seeking possibilities of co-operation in the fields of renewable energy sources, as well as in peaceful atomic energy. There is mutual interest in stimulating tourism and further development of co-operation in science and technologies.

The prospects of cooperation between India and Kazakstan are very promising. Both parties are willing and trying to interact actively and with mutual benefit, to build the networking between South Asia and Central Asia. This is the decisive response to numerous difficulties on the way. The co-operation between the two countries has been the natural result of the mutual need and common interests.

However, the current cooperation scale does not fully reflect the potential and is not proportionate to the solidity and closeness of the relationship and understanding between the two nations.

\section{Conclusion}

Relations between India and Kazakstan are ancient and historical and have always been warm and friendly. Both countries are multi-cultural, multi-linguistic, multi-ethnic societies. Rewriting of the text above:

Political rapprochement between India and Kazakstan promotes common stand towards security risks associated with religious extremism and terrorism.

India's attempts to gain a foothold in the energy sector in the region are of strategic character for her and are designed for medium and long term.

The difficulty is the lack of resources to defend the energy, trade and economic interests, namely the lack of development of the communications system.

India has a good reputation among the population of Kazakstan because of its pharmaceutical industry, advances in medicine, as well as "soft power", with which it won the hearts and minds of people.

However, the current level of the Kazak-Indian cooperation in spite of the existing potential, not high enough. It seems that the political and economic resources of bilateral relations are not fully implemented.

For its part, India would like to have greater access to the vast natural resources of Kazakstan. 
However, due to a number of bureaucratic and other hurdles nothing significant in this respect it does not occur, and the total turnover is rather small for the two countries.

It goes slowly diversify cooperation, not used by Kazakstan tremendous opportunities powerful computer and communications market in India. Both in terms of joint ventures with qualified Indian personnel, and to exit the joint production to other markets.

It should be noted that in Kazakstan's energy sector, in the presence of already well mastered
Russian, American, European and Chinese companies for the Indian business is very little low-risk projects. Nevertheless, Kazakstan quite beneficial to have another major partner in India - to maintain a balance between the major oil producers, as well as to stimulate the growth of prices for its crude oil.

Though bilateral cultural and social bonds are getting stronger, it seems that establishing a KazakIndian University would provide a new momentum and raise their status and quality.

\section{References}

1 Angel Gurría, Klaus Schwab. Competitiveness and Private Sector Development:

2 Central Asia 2011. Competitiveness Outlook, OECD Publishing, 2011

3 Nirmala Joshi. Geopolitical perspectives on Central Asia. An Indian view. India and Central Asia (classical to contemporary periods). Editors J.N.Roy, B.B.Kumar. Delhi, 2007. - P. 142.

4 K.Warkoo. India and Central Asia. Potential Implications for Power Rivalries in Eurasia. India and Central Asia. Edited P.L. Dash. New Delhi, 2012. - P. 107

5 Kazakstan. International energy data and analysis. U.S. Energy Information Administration. Last Updated: January 14, 2015. http://www.eia.gov/beta/international/analysis_includes/countries_long/Kazakstanibid

6 Sudha Mahalingam. India-Central Asia Energy Cooperation // India and Central Asia. Advancing the common interest. - New Delhi, 2004. - P. 116.

7 Lt Col Dhall, Vivek Dhall. India’s Energy Security. - New Delhi, 2013.

8 Nirmala Joshi. India - Central Asia Energy Cooperation. India and Central Asia. Edited P.L. Dash. New Delhi, 2012. - P. 51 